\title{
Paleoclimate reconstruction during MIS5a based on a speleothem from Nerja Cave, Málaga, South Spain
}

\author{
C. Jiménez de Cisneros*, E. Caballero
}

Instituto Andaluz de Ciencias de la Tierra. CSIC-UGR. Avd. de las Palmeras 4, 18100 Armilla, Granada, Spain;

*Corresponding author: cjimenezdecisneros@ugr.es, concepcion.cisneros@iact.ugr-csic.es

Received 27 November 2012; revised 28 December 2012; accepted 13 January 2013

Copyright (C) 2013 C. Jiménez de Cisneros, E. Caballero. This is an open access article distributed under the Creative Commons Attribution License, which permits unrestricted use, distribution, and reproduction in any medium, provided the original work is properly cited.

\begin{abstract}
Speleothems from Nerja Cave in southern Spain provide a record during interglacial period MIS5a. Period of speleothem deposition occurred from $70,000-90,000 \mathrm{yr}$ ago. Oxygen $\left(\delta^{18} \mathrm{O}\right)$ and hydrogen $(\delta D)$ isotope ratios of speleothem and fluid inclusions enable the reconstruction of climatic variability in this region of southern Spain. Fluid inclusions trapped in speleothems represent samples of drip water from which the speleothems grew. The isotopic compositions of cave dripwaters approximate average annual $\delta^{18} O$ and $\delta D$ of precipitation, therefore $\delta^{18} O$ can be calculated from $\mathrm{D} / \mathrm{H}$ of inclusion water using the MWL relationship $\delta D=8 \delta^{18} O+10$. The measurements of the $\delta \mathrm{D}$ values of fluid-inclusion water and $\delta^{18} O$ values from speleothems have been applied to paleoclimate reconstruction in Southern Spain indicating a colder condition than at present.
\end{abstract}

Keywords: Speleothems; Fluid Inclusions; Stable Isotope; Paleoclimate; Spain

\section{INTRODUCTION}

The interglacial periods of the late Quaternary are frequently investigated as they constitute potential analogues for our modem climate and may shed light on the key questions of natural climate variability and future developments. Speleothems (stalagmites, stalactites) have great potential for documenting the records of past climatic conditions.

The most important and frequently used climate related parameter in speleothems is $\delta^{18} \mathrm{O}$ of calcite. Provided that a stalagmite grows in isotopic equilibrium with its parent drip water, $\delta^{18} \mathrm{O}$ of calcite is dependent on temperature (an increase of $1{ }^{\circ} \mathrm{C}$ in cave air temperature results in a negative isotopic shift of $\approx 0.25 \%$ in $\delta^{18} \mathrm{O}$ of calcite). However, in all caves the temperature-dependent fractionation of ${ }^{18} \mathrm{O}$ during calcite precipitation is masked by precipitation-controlled variations in $\delta^{18} \mathrm{O}$ of cave drip water from which the speleothem is formed. $\delta^{18} \mathrm{O}$ of calcite values are therefore primarily influenced by $\delta^{18} \mathrm{O}$ of cave seepage waters and meteoric precipitation respectively, whereas $\delta^{18} \mathrm{O}$ and $\delta \mathrm{D}$ of precipitation are controlled on different times scales by a variety of climatic variables [1]. This makes $\delta^{18} \mathrm{O}$ of calcite and $\delta \mathrm{D}$ in speleothem fluid inclusions useful parameters for reconstructing climate-related changes [2]. $\delta^{18} \mathrm{O}$ values of fluid inclusion water provide direct information on the isotope composition of paleo-precipitation as cave seepage water is fed by water with a meteoric origin. Fluid inclusion water thus represents paleo-rainwater which can be used to reconstruct the hydrological cycle of the past. Studies where "fossil" rainwater can be measured directly are scarce, as rainwater normally does not fossilize. The only other direct measurements are derived from snow in ice cores. Fluid inclusions in speleothems are a new tool providing independent temperature information and direct measurements of fossil rainwater.

Speleothems commonly contain microscopic waterfilled cavities. These so-called fluid inclusions are a geologic archive of paleoprecipitation and paleotemperatures. In the present study we application a technique to analyze the stable isotope composition of fossil drip-water trapped as fluid inclusions in a stalagmite [3]. The measurements of the isotopic composition of fluid inclusion water from speleothems are complicated, the main error is due to adsorption of the inclusion water onto fresh sample fracture surfaces generated during crushing.

Stalagmite presented in this paper was colleted from Nerja Cave (Southern Spain). We present the paleoclimatic information by dating periods of stalagmite growth and by measuring $\delta^{18} \mathrm{O}$ and $\delta \mathrm{D}$ of speleothem and fluid 
inclusions respectively. The combination age of speleothem, $\delta^{18} \mathrm{O}$ and $\delta^{13} \mathrm{C}$ values of calcite and $\delta^{18} \mathrm{O}$ values of fluid inclusions can be considered to identify the climatic evolution during peak interglacial periods (MIS5a) in Southern Spain.

\section{STUDY SITE}

The Nerja Cave is located in Andalusia (southern Spain), in the province of Malaga, about $5 \mathrm{~km}$ east of the coastal town Nerja. The climate outside the cave is typically Mediterranean, with a wet season from October to February and a long dry season that is especially notable during the summer. The mean annual values for rainfall and temperature are $490 \mathrm{~mm}$ and $18.8^{\circ} \mathrm{C}$ respectively.

From the geological viewpoint, the Nerja Cave is situated on the southern border of Sierra Almijara, within the Alpujarride Complex of the Betic Cordillera (Figure 1). This complex has two lithological formations: a lower formation, made up of metapelites of Paleozoic age and an upper one made up of carbonate rocks of middle-upper Triassic [4]. At the base of this latter formation outcrop white dolomitic marbles whilst at its top appears blue calcareous marbles. The cave is developed in the dolomitic marbles which are highly fractured. In some places, this rock is completely shattered, giving rise to a typical sugar texture, with grains made up of single dolomite crystals. Outside the cave, detrital Neogene deposits outcrop discordantly over the Alpujarride rocks. Although the structure of the Alpujarride complex is very complicated on a regional scale, in the surroundings of the cave is quite simple because the marbles have an almost tabular structure, dipping $15^{\circ}-20^{\circ}$ towards the south [5]. Marbles are limited to the south by normal and strike-slip faults, which have caused significant vertical movements since Pliocene. Karst landforms (karren, dolines, sinkholes) hardly exist in these carbonate rocks but on the other hand, there is a well-developed super-
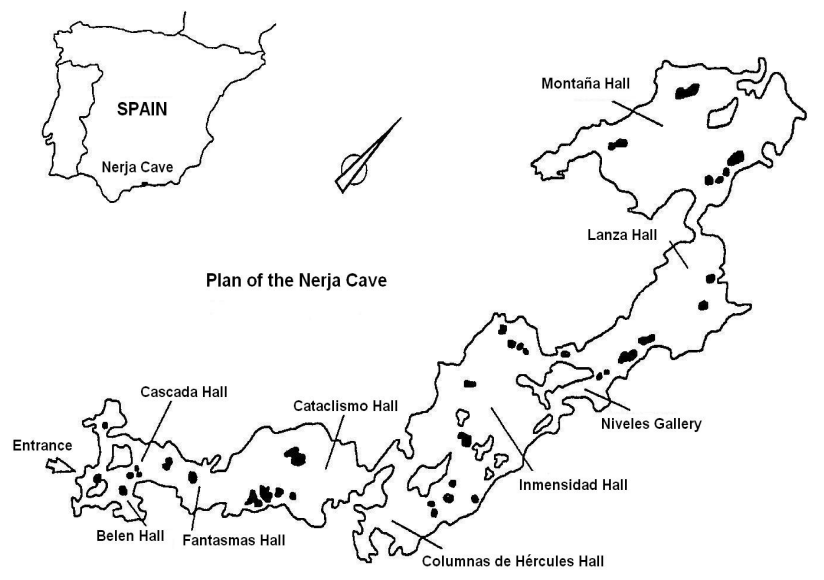

Figure 1. Map of study area. ficial drainage system, favoured by the considerable slopes of the Almijara mountain, as well as the texture of the dolomitic marbles. Karst cavities are rare in the Alpujarride carbonate aquifer; so Nerja Cave is a major exception.

The karstification process which gave rise to this cave occurred throughout the Pliocene and the Pleistocene. During the temperate and hot periods of the Quaternary age enormous quantities of calcite or aragonite deposits were generated. The Triassic marbles outcroping in Sierra Almijara constitute an aquifer of regional importance, which recharge is produced mainly by infiltration of rainwater. As a result of the Plio-Quaternary tectonic activity which affected this area, the cave is currently located in the unsaturated zone of the aquifer, above the piezometric level. The thickness of the unsaturated zone above the cave is highly variable, from 4 to $50 \mathrm{~m}$ in the external part, while in the internal area it exceeds $90 \mathrm{~m}$. Except for the gardens near the entrance, only low shrubs or soil are found above the cave. The cave has three entrance points, two of them are sinkholes (at 161 and 162 m.a.s.l.) and the third is a wider entrance which is equipped for tourist visits, found at 158 m.a.s.l. The cave extends almost horizontally between limits of 123 and 191 m.a.s.l. and occupies a volume of about $300,000 \mathrm{~m}^{3}$. This cave is an excellent fossil record of its own history and the paleoclimatic and neo-seismotectonic evolution of the area where the cave is located. Nerja Cave consists of numerous halls with a north-south orientation. The sample focus of this study is a stalagmite which was collected in the Montaña Hall. The isotopic composition of the seepage water the interior of the Nerja cave site can be considered as the mean isotopic value for precipitation water surrounding area $\left(\delta^{8} \mathrm{O}=-4.8 \%\right.$ o $[6]$.

\section{METHODOLOGY}

The mineralogical composition of the stalagmite was determined by powder X-ray diffraction (XRD) analysis using a X'PERT PRO, PANalytical equipped with a $\mathrm{Cu}$ $\mathrm{X}$-ray tube $(45 \mathrm{kV}, 40 \mathrm{~mA})$. Results from the XRD analysis show that all the studied material consists of aragonite.

The stalagmite was cut along its growth axis. One longitudinal section was polished and crystallographic observations were performed with a binocular microscope. The sample studied was between 60 and $90 \mathrm{~mm}$ long. A regular lamination with alternation of thin layers $(<0.2$ $\mathrm{mm}$ ) and thick is present. The stalagmite diameter is variable with maximum of $70 \mathrm{~mm}$. The light and dark laminae visible in hand specimen are related to changes in the fabrics. The stalagmite was divided into two parts, the first clear beige translucent crystals, in the middle displays a brown thin layer which was interpreted as a clayey inclusion, this discontinuity does not suggest a 
long interruption in deposition, and the second part greywhite crystals are observed. Based upon optical and crystallographic features, the crystals displays mainly microcrystalline fabrics and subordinately columnar ones [7]. Stalagmite consists of aragonite crystals and the mineralogical composition appears uniform throughout, with no observed evidence to indicate recrystallization of aragonite to calcite or the presence of alternating mineral laminae.

Ages were determined by Electron Spin Resonance (ESR) indicate that the samples was deposited between 70,000 - 90,000 yr ago [8,9].

Stables isotope analyses $\left(\delta^{18} \mathrm{O}\right.$ and $\left.\delta^{13} \mathrm{C}\right)$ were taken along the growth axis of speleothem and two selected growth layers (Figure 2). A total of 34 samples were colleted and the sampling for this isotopic study was carried out using a Dremmel tool fitted with a fine tip diamond studded drill bit. The drill bit was cleaned between each sample with an acid wash and de-ionized water and dried. Between five and fifteen milligrams of sample were used and $\mathrm{CO}_{2}$ was extracted from calcite at $70^{\circ} \mathrm{C}$ by reaction with $\mathrm{H}_{3} \mathrm{PO}_{4}$ [10] using a mass spectrometer "Dual Inlet" SIRA-II model (VG-Isotech, actually Micromass). Data were corrected for fractionation factors for aragonite. Results of these analyses are shown as the per-mil deviation between the sample and the Vienna Pee Dee Belemnite standard (VPDB) in delta notation. Analytical precision was $0.1 \%$ for $\delta^{18} \mathrm{O}$ and $0.05 \%$ for $\delta^{13} \mathrm{C}$.

For the analysis of the fluid inclusions the samples were crushed to $0.8-2 \mathrm{~mm}$ fragments and heated in a vacuum of $10^{-3}$ mbar. Following crushing and heating the released water is cryo-distilled into cold trap and held

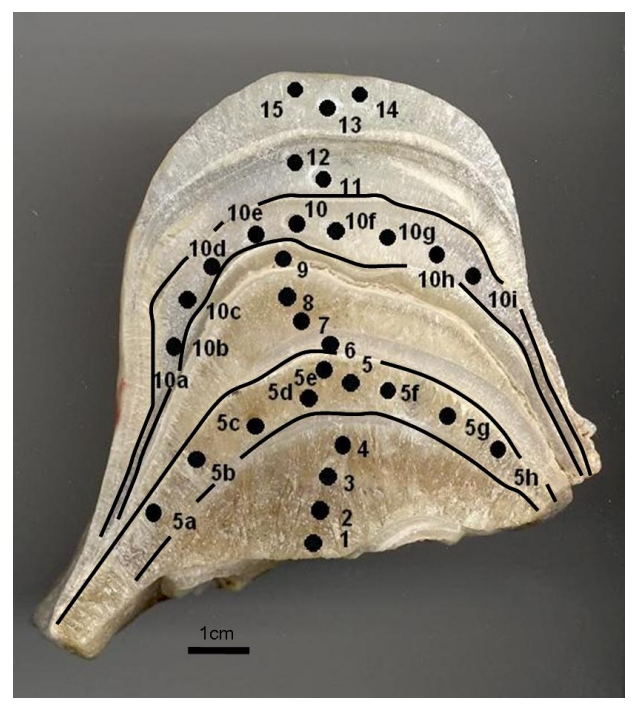

Figure 2. CN stalagmite photo. Small black circles the position of drill samples for study isotope analyses. Growth layers (5 and 10) used for isotopic equilibrium deposition test. at liquid nitrogen temperature, for a period of up to 10 minutes at static vacuum. After the initial capture, the trap temperature is raised to $-120^{\circ} \mathrm{C}$ and any $\mathrm{CO}_{2}$ and other non-condensable gases are pumped to waste. During this process $\approx 3-5 \mu$ l of water were extracted [3]. The inclusion water was trasferred to crimp top vials with rubber/PTFE crimp caps which were perfectly sealed with a crimping tool. Stable hydrogen $\left(\delta^{2} \mathrm{H}\right)$ isotopes in water samples were measured using a continuous-flow GV Instruments mass spectrometer attached to an Elemental analyzer with a liquid autosampler (EuroVector). Water samples $(0.7 \mu \mathrm{l})$ are injected into an injector port heated at $150^{\circ} \mathrm{C}$. The injector is connected to a reaction tube filled with $\mathrm{Cr}$ and heated at $1080^{\circ} \mathrm{C}$ [11]. The reduction of the water occurred into the reaction tube. The memory effect was evaluated and minimized analysing two sample replicates. The $\delta^{2} \mathrm{H}$ results are given with respect to VSMOW with a precision better than $\pm 0.5 \%$.

\section{RESULTS}

\section{1. $\delta^{18} \mathrm{O} / \delta^{13} \mathrm{C}$ of Stalagmite}

The oxygen and carbon isotope record of stalagmite is shown in Figure 3 and Table 1. $\delta^{18} \mathrm{O}$ of calcite values of stalagmite vary between $-3.9 \%$ o to $-6.2 \%$, with an average values of $-4.9 \%$. $\delta^{13} \mathrm{C}$ measurements made range $-0.2 \%$ to $-8.6 \%$ with an average value of $-2.6 \%$.

To establish a reliable palaeoclimatic record based on oxygen isotopes, stalagmites should precipitate at or near the isotope equilibrium $[12,13]$. This equilibrium during calcite precipitation was checked for using Hendy's cri-
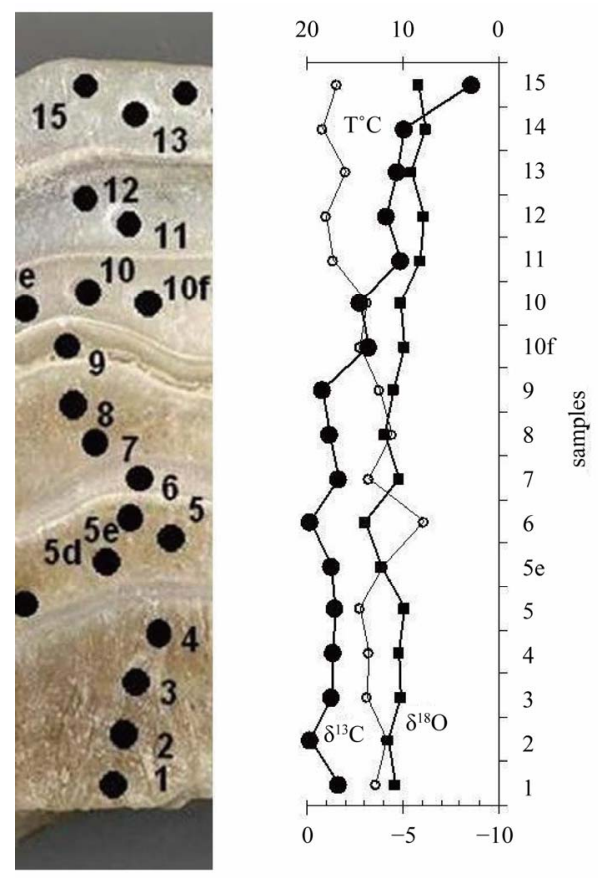

Figure 3. $\delta^{13} \mathrm{C}$ and $\delta^{18} \mathrm{O}$ record of stalagmite. 
Table 1. $\delta^{13} \mathrm{C}$ and $\delta^{18} \mathrm{O}$ data.

\begin{tabular}{cccccccc}
\hline Samples & $\boldsymbol{\delta}^{\mathbf{3}} \mathbf{C}$ & $\boldsymbol{\delta}^{\mathbf{1}} \mathbf{O}$ & $\mathbf{T}\left({ }^{\circ} \mathbf{C}\right)$ & Samples & $\boldsymbol{\delta}^{\mathbf{3}} \mathbf{C}$ & $\boldsymbol{\delta}^{\mathbf{8}} \mathbf{O}$ & $\mathbf{T}\left({ }^{\circ} \mathbf{C}\right)$ \\
\hline 1 & -1.7 & -4.6 & 13.6 & 8 & -1.2 & -4.1 & 11.9 \\
2 & -0.2 & -4.3 & 12.6 & 9 & -0.8 & -4.5 & 13.3 \\
3 & -1.3 & -4.9 & 14.6 & $10 \mathrm{f}$ & -3.2 & -5.1 & 15.3 \\
4 & -1.4 & -4.8 & 14.3 & 10 & -2.8 & -4.9 & 14.6 \\
5 & -1.5 & -5.1 & 15.3 & 11 & -4.9 & -5.9 & 18.1 \\
$5 \mathrm{e}$ & -1.3 & -4.4 & 12.9 & 12 & -4.2 & -6.1 & 18.8 \\
6 & -0.2 & -3.1 & 8.5 & 13 & -4.7 & -5.5 & 16.7 \\
7 & -1.7 & -4.8 & 14.3 & 14 & -5.1 & -6.2 & 19.2 \\
8 & -1.2 & -4.1 & 11.9 & 15 & -8.6 & -5.8 & 17.8 \\
\hline
\end{tabular}

teria [14]. Using the criteria of Hendy test [14,15] the stalagmite was tested, along a single growth layer and was cut perpendicular to its length in order to expose its growth laminae and to permit checks for a secondary alteration [16].

Two single-layer sample series were tested in order to determine if the deposition had taken place under conditions of isotope equilibrium. Each of the series included 9 and 10 samples drilled along the same growth layer. The "Hendy test 1" (samples 5a, 5b, 5c, 5d, 5e, 5, 5f, 5g, $5 \mathrm{~h})$ corresponds to internal layer and the results are given in Table 2 and graphically in the Figure 4. The "Hendy test 2" (samples 10a, 10b, 10c, 10d, 10e, 10, 10f, 10g, $10 \mathrm{~h}, 10 \mathrm{i})$ corresponds to external layer and the results are given in Table 2 and graphically in the Figure 4.

According to Hendy [14], the oxygen isotope composition of the calcite in each layer should be largely independent of the distance from the apex, when no kinetic isotopic fractionation occurs and calcite precipitates in isotopic equilibrium. Besides, no covariation between carbon and oxygen isotopes should be observed in each growth layer. Analysis of individual growth bands is commonly referred to as the "Hendy test" $[17,18]$. Isotopic disequilibrium, caused by evaporation or abnormally fast exsolution of $\mathrm{CO}_{2}$, causes both isotopes to become enriched from drip point down the side of the stalagmite where the growth layers are dipping steeply [19]. Analyses of $\delta^{13} \mathrm{C}$ and $\delta^{18} \mathrm{O}$ and the relationship between these from two randomly selected growth layers showed that the stalagmite was precipited under isotopic equilibrium and that the aragonite isotopic values do not reflect kinetic effects and thus is suitable for paleoclimate study.

\section{2. $\delta \mathrm{D}$ and $\delta^{18} \mathrm{O}$ of the Fluid Inclusions}

The results of oxygen and hydrogen isotopic composition of the recovered water has a mean value of $-6.1 \%$ and $-42.21 \%$ (VSMOW) respectively. The oxygen isotope composition has a ranging from $-6.4 \%$ to $-5.8 \%$
Table 2. $\delta^{13} \mathrm{C}$ and $\delta^{18} \mathrm{O}$ along a two-growth layer ("Hendy test").

\begin{tabular}{cccccccc}
\hline Samples & $\boldsymbol{\delta}^{\mathbf{3}} \mathbf{C}$ & $\boldsymbol{\delta}^{\mathbf{8}} \mathbf{O}$ & $\mathbf{T}\left({ }^{\circ} \mathbf{C}\right)$ & Samples & $\boldsymbol{\delta}^{\mathbf{3}} \mathbf{C}$ & $\boldsymbol{\delta}^{\mathbf{8}} \mathbf{O}$ & $\mathbf{T}\left({ }^{\circ} \mathbf{C}\right)$ \\
\hline 5a & -1.2 & -4.8 & 14.3 & $10 \mathrm{~b}$ & -1.1 & -4.8 & 14.3 \\
5b & -2.3 & -4.2 & 12.2 & $10 \mathrm{c}$ & -0.8 & -5.1 & 15.3 \\
5c & -0.8 & -4.6 & 13.6 & $10 \mathrm{~d}$ & -1.3 & -4.5 & 13.3 \\
5d & -1.4 & -5.1 & 15.3 & $10 \mathrm{e}$ & -0.8 & -4.9 & 14.6 \\
5e & -0.8 & -3.9 & 11.2 & 10 & -0.8 & -4.5 & 13.3 \\
5 & -1.5 & -5.1 & 15.3 & $10 \mathrm{f}$ & -3.2 & -5.1 & 15.3 \\
$5 \mathrm{f}$ & -1.6 & -4.3 & 12.6 & $10 \mathrm{~g}$ & -1.4 & -4.6 & 13.6 \\
$5 \mathrm{~g}$ & -1.1 & -4.4 & 12.9 & $10 \mathrm{~h}$ & -1.2 & -5.1 & 15.3 \\
5h & -0.6 & -3.9 & 11.2 & $10 \mathrm{i}$ & -1.3 & -4.9 & 14.6 \\
10a & -0.9 & -5.2 & 15.7 & & & & \\
\hline
\end{tabular}

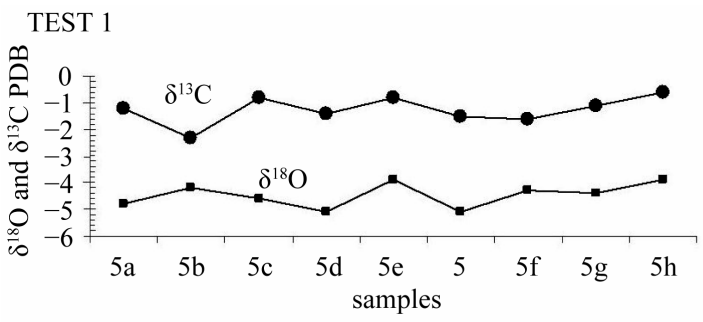

TEST 2

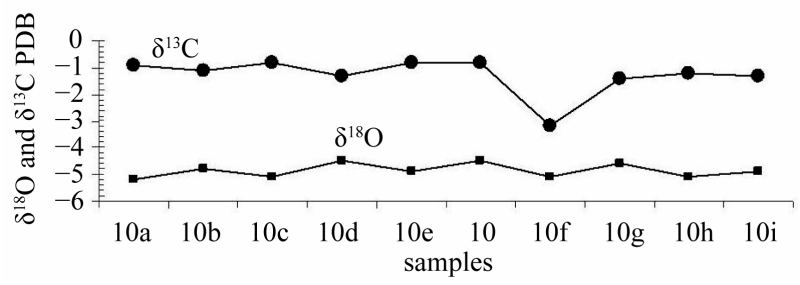

Figure 4. Isotopic analyses along growth layers (Hendy test: test 1 and test 2).

and $\delta^{2} \mathrm{H}$ values vary between $-43.23 \%$ and $-40.33 \%$. $\delta^{2} \mathrm{H}$ and $\delta^{18} \mathrm{O}$ values combined plot on the Global Meteoric Water Line (GMWL; Figure 5). In this figure also shows the values of the rainwater, dripwater [6] and fluid inclusions from speleothems of the Nerja Cave [3].

\subsection{Paleotemperatures Calculations}

In Table 1, we have included the paleotemperatures calculated, for each sample drilling in the section of stalagmite analysed, using the equation for temperature-dependence for aragonite [20]. The paleotemperatures was calculated using the average value $\delta^{18} \mathrm{O}_{\mathrm{VS} M O W}$ recovered in the extraction of fluid inclusions waters. When inserting the value $\delta^{18} \mathrm{O}_{\text {VSMOW }}=-6.1 \%$ o (average value of $\delta^{18} \mathrm{O}$ from fluid inclusions waters) in the equation of Grossman and $\mathrm{Ku}[20]$, the calculated temperatures vary from minimum $9^{\circ} \mathrm{C}$ and maximum $19^{\circ} \mathrm{C}$ being the average value of $14^{\circ} \mathrm{C}$. The temperatures values obtained are lower to the one prevailing at present $\left(19^{\circ} \mathrm{C}-21^{\circ} \mathrm{C}\right)$. 


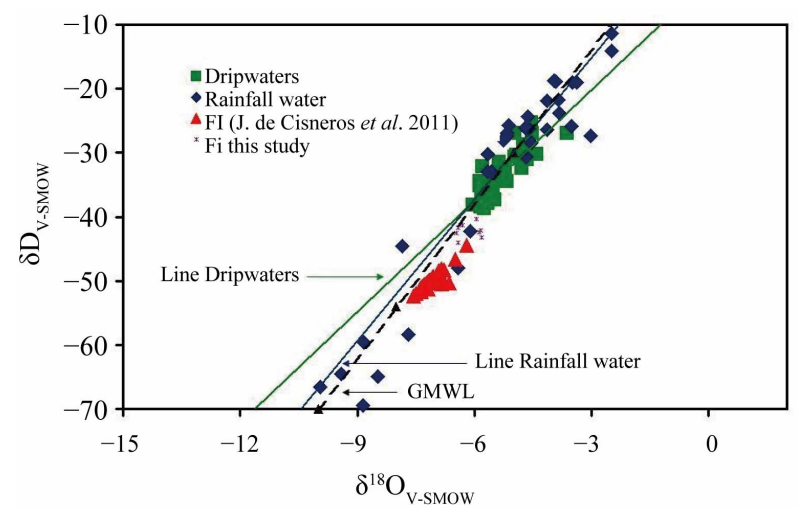

Figure 5. Oxygen and hydrogen isotopic composition of the recovered water from fluid inclusions. The isotopic data the rainwater and dripwaters of the Nerja Cave are presented on the Global Meteoric Water Line (GMWL).

In the two selected growth layers the mean values obtained of palaeotemperatures are to $13.2^{\circ} \mathrm{C}-14.6^{\circ} \mathrm{C}$ for "Hendy test 1 and test 2 " respectively, using a $\delta^{18} \mathrm{O}_{\text {SMOW }}$ $=-6.1 \%$ obtained from fluid inclusions. We can be observed that the temperatures values obtained are something cooler than at present, being a little warmer in the test 2 .

The stalagmite shows two parts, a colder and a warmer phase. The first growth phase reveals the most enriched values of ${ }^{18} \mathrm{O}$ (mean value of $-4.5 \%$ ) and relatively high carbon signature (mean value of $-1.1 \%$ ). In the upper part relatively decreasing values are recorded being the average values of $-4.8 \%$ for $\delta^{13} \mathrm{C}$ and $-5.6 \%$ for $\delta^{18} \mathrm{O}$.

\section{DISCUSSION}

Isotopic studies of speleothems have focused on $\delta^{18} \mathrm{O}$ of calcite as the principal paleoclimatic proxy, supplemented by $\delta^{13} \mathrm{C}$ as an indicator of changes in soil bioactivity. Other studies have also shown the potential for direct measurement of paleotemperatures using measurement of $\delta^{18} \mathrm{O}$ and $\delta \mathrm{D}$ of fluid inclusions [21-26].

The stalagmite was deposited during the time interval 70 - 90 ky ago, in the ending isotopic stage 5 (interglacial period MIS5a), when the phreatic level of the waters in the cave decreased [27]. This period in the cave is characterized by maximum growth of speleothems and the precipitation is associated with warm and relatively wet periods [28]. On the other hand, when no evaporation occurs at the surface or in the epikarst, $\delta^{18} \mathrm{O}$ and $\delta \mathrm{D}$ of cave drip waters are close to mean annual isotopic composition of precipitation. In Nerja Cave, these effects seem to be negligible because the isotopic composition of cave drip waters is very close to those of precipitation above the cave [6]. Therefore, speleothems formed from these waters can be considered to be faithful recorders for $\delta^{18} \mathrm{O}$ and $\delta \mathrm{D}$ of local precipitation in the past. A uniform stalagmite growth rate indicates an accretion rate of about $3 \mathrm{~mm} / \mathrm{ka}$.

The $\delta^{13} \mathrm{C}$ and $\delta^{18} \mathrm{O}$ values in the stalagmite show large variations. For $\delta^{13} \mathrm{C}$ these fluctuations are often explained by changes in vegetation $[29,30]$, the most obvious changes being related to photosynthetic pathways. ${ }^{13} \mathrm{C}$ of speleothem comes from limestone $\mathrm{CaCO}_{3}$ and soil $\mathrm{CO}_{2}$. The changes in $\delta^{13} \mathrm{C}$ of speleothems reflect only the variation of $\delta^{13} \mathrm{C}$ in soil $\mathrm{CO}_{2}$, for $\delta^{13} \mathrm{C}$ of $\mathrm{CaCO}_{3}$ in limestone is nearly constant. The $\delta^{13} \mathrm{C}$ record roughly follows the same trend as the $\delta^{18} \mathrm{O}$ record [31]. When the correlation between $\delta^{13} \mathrm{C}$ and $\delta^{18} \mathrm{O}$ is good, as it is in this case where $\mathrm{r}=0.913$, we have a clear correlation between hydrology and vegetation above the cave. The higher $\delta^{13} \mathrm{C}$ values may reflect, at least in part, an enrichment of the heavier ${ }^{13} \mathrm{C}$ isotope in the aragonite crystals. The equilibrium carbon isotope composition of aragonite is $\sim 2 \%$ - 3\%o heavier than calcite [32], and kinetic effects typically result in aragonite values that are even higher than expected [33]. McMillan [34] reported a 2.5\% difference in $\delta^{13} \mathrm{C}$ between aragonite and calcite layers in the same speleothem from Grotte de Clamouse, France, and Zhang [35] observed a consistent ${ }^{13} \mathrm{C}$ enrichmentof $5 \%$ - 7\%o between coeval aragonite and calcite speleothems from Marengo Cave, USA. The variation in the $\delta^{13} \mathrm{C}$ signal is used here to illustrate the sensitivity of terrestrial climate response in the southern Mediterranean region to events that occurred during the last inter-glacial period $[36,37]$ and correlates directly with a similar event in the speleothem from Cova de Cala Falcó, Mallorca, Spain [37].

The oxygen isotope data permit further constraints on the processes that governed the formation of this speleothem. Mean annual air temperature is known to correlate with the oxygen isotope composition of mean annual precipitation, the latter being higher during warm years and vice versa [38]. Oxygen isotope records are plotted against depth along the stalagmite apex in Figure 6, together with those obtained from NGRIP $\delta^{18} \mathrm{O}$ on the ss09sea timescale [39]. The $\delta^{18} \mathrm{O}$ signal in the stalagmite is primarily a response to two factors: 1) isotopic fractionation in the meteoric system of ocean water, water vapor, and precipitation; and 2) isotopic fractionation in the cave system, that is, the temperature-dependent fractionation in the cave drip water/calcite deposition system. Paleoenvironmental and paleoclimatic conditions expressed in the $\delta^{13} \mathrm{C}-\delta^{18} \mathrm{O}$ time-serie record define two intervals: the first stage characterized by decreased vegetation associated with cool-dry conditions during this period, the high values suggest that vegetative productivity declined.

These values may also reflect lower drip rates, consistent with decreased precipitation, and degassing in the epikarts. 


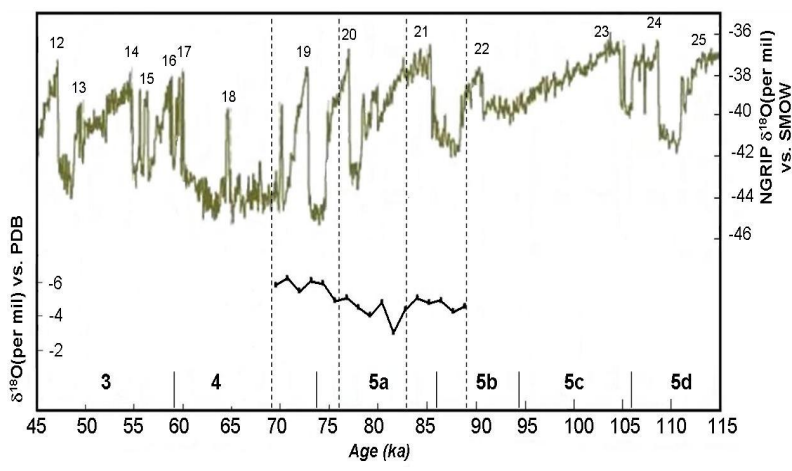

Figure 6. Oxygen isotopic values versus age profile. Higher $\delta^{18} \mathrm{O}$ values are indicative of warner (and/or drier) climatic conditions. Distances from the top of the stalagmite are shown on the top x-axis (NGRIP members, 2004).

The cold and dry conditions favoured enhanced cave air ventilation, which enhanced degassing and the precipitation of higher speleothem $\delta^{13} \mathrm{C}-\delta^{18} \mathrm{O}$ values. The second stage the lower $\delta^{13} \mathrm{C}$ and $\delta^{18} \mathrm{O}$ values suggets more biological productivity associated with warm conditions. The low $\delta^{13} \mathrm{C}$ values reflect relatively high drip rates fed by abundant precipitation and a lower degree of mixing between atmospheric and biogenic $\mathrm{CO}_{2}$. Under these conditions, weakened cave air ventilation resulted in reduced degassing and lower speleothem $\delta^{13} \mathrm{C}$ values.

The oxygen and carbon isotope variations measured suggest that during MIS 5a temperature was cooler than at present in the south of Spain. The stalagmite record contributes to enhanced understanding of climatic variability in this region of southern Spain.

\section{CONCLUSIONS}

This study shows that hydrogen isotope analyses of speleothem fluid inclusions in combination with oxygen isotope analyses of speleothem enable the reconstruction of climatic variability in this region of southern Spain. Fluid inclusion isotope analysis drastically improves paleotemperature reconstructions based on speleothem calcite $\delta^{18} \mathrm{O}$ data, because it provides the $\delta^{18} \mathrm{O}$ value of cave drip water through time, which is usually the most important unknown in paleotemperature equations. On the other hand, $\delta^{13} \mathrm{C}$ values of stalagmite provide information about the history of vegetation and climatic conditions. Changes in biological productivity and inorganic processes in response to climatic conditions associated a mediterranean climate originate the variations in the $\delta^{13} \mathrm{C}$ values. Results for the Nerja Cave show the isotopic record from MIS5a which reveals a relatively stable climate and indicates colder conditions than at present.

\section{ACKNOWLEDGMENTS}

This research was supported by Project CGL2007-61876/BTE. We thank Fundation of Nerja Cave for access to the sites.

\section{REFERENCES}

[1] Rozanski, K., Araguás-Araguás, L. and Gonfiantini R., (1992) Relation between long-term trends of O-18 isotope composition of precipitation and climate. Science, 258, 981-985. doi:10.1126/science.258.5084.981

[2] Fleitmann, D., Burns, S.J., Neff, U., Mangini, A. and Matter A. (2003) Changing moisture sources over the last 330.000 years in northern Oman from fluid-inclusion evidence in speleothems. Quaternary Research, 60, 223-232. doi:10.1016/S0033-5894(03)00086-3

[3] Jiménez de Cisneros, C., Caballero, E., Vera, J.A. and Andreo, B. (2011) An optimized thermal extraction system for preparation of water from fluid inclusions in speleothems. Geologica Acta, 9, 149-158.

[4] Sanz de Galdeano, C. (1990) Estructura y estratigrafía de la Sierra de los Guájares y sectores próximos (conjunto Alpujárride, Cordilleras Béticas). Estudios Geológicos, 46, 123-134. doi:10.3989/egeol.90461-2444

[5] Andreo, B., Carrasco, F. and Sanz de Galdeano, C. (1993) Estudio geológico del entorno de la Cueva de Nerja. In: Carrasco, F., Ed., Trabajos Sobre la Cueva de Nerja, Málaga, 3, 25-50.

[6] Caballero, E., Jiménez de Cisneros, C. and Reyes, E. (1996) A stable isotope study of cave seepage waters. Applied Geochemistry, 11, 583-587. doi:10.1016/0883-2927(96)00026-1

[7] Frisia, S., Borsato, A., Fairchild, I. and McDermott, F. (2000) Calcite fabrics, growth mechanismsand environments of formation in speleothems from the Italian Alps and Southwestern Ireland. Journal of Sedimentary Research, 70, 1183-1196. doi:10.1306/022900701183

[8] Durán, J.J. (1996) Los sistemas kársticos de la provincia de Málaga y su evolución: Contribución al conocimiento paleoclimático del Cuaternario en el Mediterráneo occidental. Ph.D. Thesis, University of Madrid, Madrid.

[9] Durán, J.J., Grün, R. and Ford, D.C. (1993) Dataciones geocronológicas absolutas (Métodos E.S.R. y Series de Uranio) en la Cueva de Nerja y su entorno. Implicaciones evolutivas, paleoclimáticas y neosintectónicas. In: Carrasco, F., Ed., Trabajos Sobre la Cueva de Nerja. Málaga, 3, 233-248.

[10] McCrea, J.M. (1950) On the isotopic chemistry of carbonates and a paleotemperature scale. Journal of Chemical Physics, 18, 849-857. doi:10.1063/1.1747785

[11] Morrison, J., Brockwell, T., Merren, T., Fourel, F. and Phillips, A.M. (2001) On-line high-precision stable hydrogen isotopic analyses on nanoliter water samples. Analytical Chemistry, 73, 3570-3575. doi:10.1021/ac001447t

[12] Schwarcz, H.P., Harmon, R.S., Thompson, P. and Ford, D.C. (1976) Stable isotope studies of fluid inclusions in speleothems and their paleoclimatic effect. Geochimica et Cosmochimica Acta, 40, 657-665. doi:10.1016/0016-7037(76)90111-3

[13] Schwarcz, H.P. (1986) Geochronology and isotopic geochemistry of speleothems. In: Fritz, P. and Fontes, Ch. 
Eds., Handbook of Environmental Isotope Geochemistry, Elsevier, Amsterdam, 271-303.

[14] Hendy, C.H. (1971) The isotopic geochemistry of speleothems. I. The calculation of the effects of differents modes of formation on the isotopic composition of speleothems and their applicability as paleoclimatic indicators. Geochimica et Cosmochimica Acta, 35, 801-824. doi:10.1016/0016-7037(71)90127-X

[15] Bar-Matthews, M., Ayalon, A., Matthews, A., Halicz, L. and Sass, E. (1993) The Soreq cave speleothems as indicators of paleoclimate variations. Geological Survey of Israelian Current Research, 8, 1-3.

[16] Bar-Matthews, M., Ayalon, A and Kaufman, A. (1997) Late Quaternary paleoclimate in the eastern Mediterranean region from stable isotope analysis of speleothems at Soreq Cave, Israel. Quaternary Research, 47, 155-168. doi:10.1006/qres.1997.1883

[17] Linge, H., Lauritzen, S.E. and Lundberg, J. (2001) Stable isotope stratigraphy of a late last interglacial speleothem from Rana, Northern Norway. Quaternary Research, 56, 155-166

[18] Linge, H., Lauritzen, S.E., Lundberg, J. and Berstad, J.M. (2001) Stable isotope stratigraphy of Holocene speleothems: Examples from cave system in Rana, northern Norway. Palaeogeography, Palaeoclimatology, Palaeoecology, 167, 209-224.

doi:10.1016/S0031-0182(00)00225-X

[19] Fantidis, J. and Ehhalt, D.H. (1970) Variations of the carbon and oxygen composition in stalagmites and stalactites: Evidence of non-equilibrium isotopic fractionation. Earth Planetary Science Letters, 10, 136-144. doi:10.1016/0012-821X(70)90075-0

[20] Grossman, E.T. and Ku, T.L. (1981) Aragonite-water isotopic paleotemperature scale based on the benthic foraminifera Hoeglundia elegans. Abstracts with Programs. Geographical Society of America, Colorado.

[21] Dennis, P.F., Rowe, P.J. and Atkinson, T.C. (2001) The recovery and isotopic measurement of water from fluid inclusions in speleothems. Geochimica et Cosmochimica Acta, 65, 871-884. doi:10.1016/S0016-7037(00)00576-7

[22] McGarry, S., Bar-Matthews, M., Matthews, A., Vaks, A., Schilman, B. and Ayalon, A. (2004) Constraints on hydrological and paleotemperature variations in the Eastern Mediterranean region in the last 140 ka given by the $\delta \mathrm{D}$ values of speleothem fluid inclusions. Quaternary Science Reviews, 23, 919-934.

doi:10.1016/j.quascirev.2003.06.020

[23] Serefiddin, F., Schwarcz, H. and Ford, D. (2005) Use of hydrogen isotope variations in speleothem fluid inclusions as an independent measure of paleoclimate. Geological Society of America Special, 395, 43-53.

[24] Vonhof, H.B., van Breukelen, M.R., Postma, O., Rowe, P.J., Atkinson, T.C. and Kroon, D. (2006) A continuousflow crushing device for on-line $\delta^{2} \mathrm{H}$ analysis of fluid inclusion water in speleothems. Rapid Communications in Mass Spectrometry, 20, 2553-2558. doi: $10.1002 / \mathrm{rcm} .2618$

[25] Verheyden, S., Genty, D., Cattani, O. and van Breukelen, M.R. (2008) Water release patterns of heated speleothem calcite and hydrogen isotope composition of fluid inclusions. Chemical Geology, 247, 266-281.

doi:10.1016/j.chemgeo.2007.10.019

[26] Fleitmann, D. and Matter, A. (2009) The speleothem record of climate variability in Southern Arabia. C.R. Geoscience, 341, 633-642. doi:10.1016/j.crte.2009.01.006

[27] Jiménez de Cisneros, C., Caballero, E., Vera, J.A., Durán, J.J. and Juliá, R. (2003) A record of Pleistocene climate from a stalactite, Nerja Cave, southern Spain. Palaeogeo Palaeoclim Palaeoecol, 189, 1-10. doi:10.1016/S0031-0182(02)00589-8

[28] Jiménez de Cisneros, C. and Caballero, E. (2010) $\delta^{13} \mathrm{C}$ values from a stalagmite at the Nerja Cave, South Spain. In: Andreo, B., Carrasco, F., Durán, J.J. and LaMoreaux, J.W., Eds., Advances in Research in Karts Media, Springer, Berlin, 497-501. doi:10.1007/978-3-642-12486-0 76

[29] Dorale, J.A., González, L.A., Reagan, M.K., Picknett, D.A., Murrell, M.T. and Baker, R.G. (1992) A high-resolution record of holocene climate change in speleothem calcite from Cold Water cave, northeast Iowa. Science, 258, 1626-1630. doi:10.1126/science.258.5088.1626

[30] Dorale, J.A., Edwards, R.L., Ito, E. and González, L.A. (1998) Climate and vegetation history of Midcontinent from 75 to $25 \mathrm{ka}$ : A speleothem record from crevice cave, Missouri, USA. Science, 282, 1871-1871. doi:10.1126/science.282.5395.1871

[31] Jiménez de Cisneros, C. and Caballero, E. (2011) Carbon isotope values as paleoclimatic indicators. Study on stalagmite from Nerja Cave, South Spain. Carbonates Evaporites, 26, 41-46. doi:10.1007/s13146-011-0049-2

[32] Morse, J. and Mackenzie, F. (1990) Geochemistry of sedimentary carbonates. Developments in Sedimentology. Elsevier, Amsterdam.

[33] Frisia, S., Borsato, A., Fairchild, I., McDermott, F. and Selmo, E. (2002) Aragonite-calcite relationships in speleothems (Grotte de Claumose, France): environment, fabrics and carbonate geochemistry. Journal of Sedimentary Research, 72, 687-699. doi:10.1306/020702720687

[34] McMillan, E., Fairchild, I., Frisia, S., Borsato, A. and McDermott, F. (2005) Annual trace element cycles in calcite-aragonite speleothems: Evidence of drought in the western Mediterranean 1200-1100 yr. BP. Journal of Quaternary Science, 20, 423-433. doi:10.1002/jqs.943

[35] Zhang, R., Schwarcz, H., Ford, D., Serefiddin, F. and Beddows, P. (2008) An absolute paleotemperature record from 10 to $6 \mathrm{Ka}$ inferred from fluid inclusion $\mathrm{D} / \mathrm{H}$ ratios of a stalagmite from Vancouver Island, British Columbia, Canada. Geochimica et Cosmochimica Acta, 72, 10141026. doi:10.1016/j.gca.2007.12.002

[36] Martrat, B., Grimalt, J., Lopez-Martinez, C., Cacho, I., Sierro, F.J., Flores, J.A., Zahn, R., Canals, M., Curtis, J.H. and Hodell, D.A. (2004) Abrupt temperature changes in the Western Mediterranean over the past 250,000 years. Science, 306, 1762-1765. doi:10.1126/science.1101706

[37] Hodge, E., Richards, D.A., Smart, P.L., Ginés, A. and Mattey, D.P. (2008) Sub-millennial climate shifts in the western Mediterranean during the last glacial period recorded in a speleothem from Mallorca, Spain. Journal of Qua- 
ternary Science, 23, 713-718.

[38] Dansgaard, W. (1964) Stable isotopes in precipitation. Tellus, 16, 436-448.

doi:10.1111/j.2153-3490.1964.tb00181.x
[39] North Greeland Ice Core Project Members (2004) Highresolution record of Northern hemisphere climate extending into the last interglacial period. Nature, 431, 147-151. doi:10.1038/nature02805 